\title{
EDITORIAL
}

\section{FRAILTY AND COGNITION: LINKING TWO COMMON SYNDROMES IN OLDER PERSONS}

\author{
T.K. MALMSTROM ${ }^{1}$, J.E. MORLEY²
}

\begin{abstract}
1. Department of Neurology \& Psychiatry and Division of Geriatric Medicine, Saint Louis University School of Medicine, St. Louis, Missouri; 2. Divisions of Geriatric Medicine and Endocrinology, Saint Louis University School of Medicine, St. Louis, Missouri. Corresponding author: John E. Morley, MB, BCh, Director, Divisions of Geriatric Medicine and Endocrinology, Saint Louis University School of Medicine, 1402 S. Grand Blvd., M238, St. Louis, Missouri 63104, Email: morley@slu.edu
\end{abstract}

In this issue an International Consensus Panel has suggested that geriatricians should recognize a new syndrome of Cognitive Frailty (1). Physical frailty has now been recognized as an important syndrome in older persons (2-7). An international panel representing 6 international groups has recently suggested that all persons over the age of 70 years should be screened for physical frailty by simple, validated screening tests such as the FRAIL (8-13) (Table 1).

Table 1

The Simple "FRAIL” Questionnaire Screening Tool

$(3-5=$ frail; $1-2=$ prefrail $)$

Fatigue: Are you fatigued?

Resistance: Cannot walk up one flight of stairs?

Aerobic: Cannot walk one block?

Illnesses: Do you have more than 5 illnesses?

Loss of weight: Have you lost more than $5 \%$ of your weight in the last 6 months?

The concept of "cognitive frailty" appears to be an important one, recognizing the synergistic effect that Mild Cognitive Impairment (MCI) can have in persons with physical frailty. There is increasing evidence that psychological and social problems can accelerate the development of disability, hospitalization, nursing home placement and death (14-20). In some cases the reasons for the synergistic effect are obvious while in others they are more complex and may depend on similar pathophysiological processes accelerating both problems $(1,21)$. Diabetes mellitus is a condition that produces both physical frailty by accelerating sarcopenia $(22,23)$ and cognitive frailty $(24,25)$. In addition, in persons with diabetes who develop cognitive frailty, this will worsen the ability to adequately manage diabetes and thus accelerate physical frailty (26). Dual tasking is a condition in which persons with an executive function deficit have decreased control over their walking when required to carry out another task $(27,28)$. Dual tasking represents one obvious interaction where both cognitive and physical frailty are synergistic with one another. Both the Gerontopole in Toulouse and the "Kihon Checklist" in Japan have tacitly recognized the importance of this synergism in their screening tests (29-32).
If Cognitive Frailty is going to become a widely accepted syndrome, it is essential that a simple screening test, similar to the FRAIL, is developed for Mild Cognitive Impairment. At present, two tests that take about 7 minutes to carry out have been validated as screening tests for amnestic Mild Cognitive Impairment (33). These tests are the Montreal Cognitive Assessment (MoCA) and the VA Saint Louis University Mental Status (SLUMS) examination (34-38). However, for rapid screening by the general practitioner these tests take too long. Asking the simple question of "are you having memory problems?" and then referring to a specialist may be one solution. Another is to develop a shorter mental status examination. The Rapid Cognitive Screen (RCS) is one such version that takes approximately 2 minutes to complete (Table 2). Unlike the MiniCog, which only identifies dementia, we have validated that the RCS has good sensitivity and specificity for identifying amnestic MCI (manuscript in preparation). Thus, a test like the RCS may prove, in concert with the frail, to be an excellent tool to identify "Cognitive Frailty."

Table 2

The Rapid Cognitive Screen (RCS) - International Version

(0-5 = dementia; 6-7 = MCI; 8-10 = normal)

Recall: Five objects - Apple, Pen, Tie, House, Car. [Recall objects after clock drawing; 5 points.]

Clock Drawing: Draw with time at ten minutes to eleven o'clock. [4 points]

Insight: Jill was a very successful stockbroker. She made a lot of money on the stock market. She then met Jack, a devastatingly handsome man. She married him and had three children. They lived in Rome. She then stopped work and stayed at home to bring up her children. When they were teenagers, she went back to work. She and Jack lived happily ever after.

What country did they live in? [1 point]

It is important to recognize that a number of treatment strategies exist for MCI. These include identifying treatable causes of cognitive decline (e.g., vitamin B12 deficiency, hypothyroidism, chronic infections, depression, hearing and visual deficits and anticholinergic drugs) (39-42). In addition, there is now solid data suggesting that physical exercise will delay or reverse early cognitive decline as well as physical 


\section{FRAILTY AND COGNITION: LINKING TWO COMMON SYNDROMES IN OLDER PERSONS}

frailty (43-48). There is some evidence suggesting that hypogonadism in males is associated with rapid transit from MCI to Alzheimer's disease and that testosterone replacement may improve cognitive function (49-51). Nutritional supplements, such as Souvenaid® or alpha lipoic acid may also slow cognitive decline (52-55).

Finally, it needs to be recognized that there is a broader spectrum of psychosocial risk factors for creating frailty. These include social factors such as poverty but also stressful events such as an earthquake (56) or even a pure psychological stress such as Britain returning Hong Kong to China (57). Obviously dysphoria represents another psychosocial factor that can aggravate frailty $(58,59)$. For this reason, we have created a psychosocial frailty scale "SOCIAL" for which we have a preliminary validation (Table 3 ).

\section{Table 3}

Screening Test for Psychosocial Frailty

(4-6 = frail; $2-3=$ prefrail $)$

Sadness

Outside activity

Cognition

Income adequacy

Attachment to neighborhood

Lethargy

The international consensus conference has made an important addition to our geriatric armamentarium in recognizing "Cognitive Frailty" as an important geriatric syndrome. We now need future research validating that the recognition and treatment of "Cognitive Frailty" improves outcomes in older persons.

\section{References}

1. Kelaiditi E, Cesari M, Canevelli, et al. Cognitive frailty: Rational and definition from an (I.A.N.A./I.A.G.G.) International Consensus Group. J Nutr Hlth Aging 2013; (In press).

2. Rockwood K, Abeysundera MJ, Mitnitski A. How should we grade frailty in nursing home patients? J Am Med Dir Assoc 2007;8:595-603.

3. Morley JE. Frailty: Diagnosis and management. J Nutr Health Aging 2011;15:667670.

4. Sourdet S, Rougé-Bugat ME, Vellas B, Forette F. Frailty and aging. J Nutr Health Aging 2012;16:283-284.

5. Gobbens RJ, van Assen MA, Luijkx KG, et al. Determinants of frailty. J Am Med Dir Assoc 2010;11:356-364.

6. Peters LL, Boter H, Buskens E, Slaets JP. Measurement properties of the Groningen Frailty Indicator in home-dwelling and institutionalized elderly people. J Am Med Dir Assoc 2012;13:546-551.

7. Hoogendijk EO, van Hout HP. Investigating measurement properties of the Groningen Frailty Indicator: A more systematic approach is needed. J Am Med Dir Assoc 2012;13:757; author reply 757-758.

8. Morley JE, Vellas B, Abellan van Kan G, et al. Frailty consensus: A call to action. J Am Med Dir Assoc 2013;14:392-397.

9. Morley JE, Malmstrom TK, Miller DK. A simple frailty questionnaire (FRAIL) predicts outcomes in middle aged African Americans. J Nutr Health Aging 2012;16:601-608.

10. Abellan van Kan G, Rolland YM, Morley JE, Vellas B. Frailty: Toward a clinical definition. J Am Med Dir Assoc 2008;9:71-72.

11. Woo J, Leung J, Morley JE. Comparison of frailty indicators based on clinical phenotype and the multiple deficit approach in predicting mortality and physical limitation. J Am Geriatr Soc 2012;60:1478-1486.

12. Hyde Z, Flicker L, Almeida OP, et al. Low free testosterone predicts frailty in older men: The health in men study. J Clin Endocrinol Metab 2010;95:3165-3172.

13. Ravindrarajah R, Lee DM, Pye SR; The European Male Aging Study Group. The ability of three different models of frailty to predict all-cause mortality: Results from the European Male Aging Study (EMAS). Arch Gerontol Geriatr 2013;18:pii:S01674943(13)00107-6 (Epub ahead of print).

14. Shimada H, Makizako H, Doi T, et al. Combined prevalence of frailty and mild cognitive impairment in a population of elderly Japanese people. J Am Med Dir Assoc 2013; 14:518-524.

15. Auyeung TW, Lee JS, Kwok T, Woo J. Physical frailty predicts future cognitive decline - a four-year prospective study in 2737 cognitively normal older adults. J Nutr Health Aging 2011;15:690-694.

16. Jacobs JM, Cohen A, Bin-Mor E, et al. Frailty, cognitive impairment and mortality among the oldest old. J Nutr Health Aging 2011;15:678-682.

17. Dramé M, Novella JL, Jolly D, et al. Rapid cognitive decline, one-year institutional admission and one-year mortality: Analysis of the ability to predict and inter-tool agreement of four validated clinical frailty indexes in the SAFEs cohort. J Nutr Health Aging 2011;15:699-705.

18. Yassuda MS, Lopes A, Cachioni M, et al. Frailty criteria and cognitive performance are related: Data from the FIBRA study in Ermelino Matarazzo, São Paulo, Brazil. J Nutr Health Aging 2012;16:55-61.

19. Cano C, Samper-Ternent R, Al Snih S, et al. Frailty and cognitive impairment as predictors of mortality in older Mexican Americans. J Nutr Health Aging 2012;16:142-147.

20. Mitnitski A, Fallah N, Rockwood MR, Rockwood K. Transitions in cognitive status in relation to frailty in older adults: A comparison of three frailty measures. J Nutr Health Aging 2011;15:863-867.

21. Mulero J, Zafilla P, Martinez-Cacha A. Oxidative stress, frailty and cognitive decline. J Nutr Health Aging 2011;15:756-760.

22. Leenders M, Verdijk LB, van der Hoeven L, et al. Patients with Type 2 diabetes show a greater decline in muscle mass, muscle strength, and functional capacity with aging. J Am Med Dir Assoc 2013; doi:pii:S1525-8610(13)00096-0 (Epub ahead of print).

23. Morley JE. Diabetes mellitus: "The times they are a-changin." J Am Med Dir Assoc 2012;13:574-575

24. Chau PH, Woo J, Lee $\mathrm{CH}$, et al. Older people with diabetes have higher risk of depression, cognitive and functional impairments: Implications for diabetes services. J Nutr Health Aging 2011;15:751-755.

25. Luchsinger JA, Palmas W, Teresi JA, et al. Improved diabetes control in the elderly delays global cognitive decline. J Nutr Health Aging 2011;15:445-449.

26. Sinclair A, Morley JE, Rodriguez-Mañas L, et al. Diabetes mellitus in older people: Position statement on behalf of the International Association of Gerontology and Geriatrics (IAGG), the European Diabetes Working Party for Older People (EDWPOP), and the International Taskforce on Experts in Diabetes. J Am Med Dir Assoc 2012;13:497-502.

27. Beauchet O, Annweiler C, Dubost V, et al. Stops walking when talking: A predictor of falls in older adults? Eur J Neurol 2009;16:786-795.

28. Yogev-Seligmann G, Hausdorff JM, Giladi N. The role of executive function and attention in gait. Mov Disord 2008;23:329-342.

29. Rougé Bugat ME, Cestac P, Oustric S, et al. Detecting frailty in primary care: A major challenge for primary care physicians. J Am Med Dir Assoc 2012;13:669-672.

30. Vellas B, Cestac P, Morley JE. Implementing frailty into clinical practice: We cannot wait. J Nutr Health Aging 2012;16:599-600.

31. Subra J, Gillette-Guyonnet S, Cesari M, et al. The integration of frailty into clinical practice: Preliminary results from the Gérontopôle. J Nutr Health Aging 2012;16:714-720.

32. Fukutomi E, Okumiya K, Wada T, et al. Importance of cognitive assessment as part of the "Kihon Checklist" developed by the Japanese Ministry of Health, Labor and Welfare for prediction of frailty at a 2-year follow-up. Geriatr Gerontol Int 2013;13:654-662.

33. Cruz-Oliver DM, Morley JE. Early detection of cognitive impairment: Do screening tests help? J Am Med Dir Assoc 2010;11:1-6.

34. Khater MS, Abouelezz NF. Nutritional status in older adults with mild cognitive impairment living in elderly homes in Cairo, Egypt. J Nutr Health Aging 2011;15:104-108.

35. Tariq SH, Tumosa N, Chibnall JT, et al. Comparison of the Saint Louis University mental status examination and the mini-mental state examination for detecting dementia and mild neurocognitive disorder - a pilot study. Am J Geriatr Psychiatr 2006;14:900-910.

36. Cruz-Oliver DM, Malmstrom TK, Allen CM, et al. The Veterans Affairs Saint Louis University mental status exam (SLUMS exam) and the Mini-mental status exam as predictors of mortality and institutionalization. J Nutr Health Aging 2012;16:636641.

37. Cao L, Hai S, Lin X, et al. Comparison of the Saint Louis University Mental Status Examination: The Mini-Mental State Examination and the Montreal Cognitive Assessment in detection of cognitive impairment in Chinese elderly from the geriatric 


\section{JNHA: COGNITIVE FRAILTY}

department. J Am Med Dir Assoc 2012;13:626-629.

38. Feliciano L, Horning SM, Klebe KJ, et al. Utility of the SLUMS as a cognitive screening tool among a nonveteran sample of older adults. Am J Geriatr Psychiatry 2013;21:623-630.

39. Fitzgerald SP, Bean NG. An analysis of the interactions between individual comorbidities and their treatments - implications for guidelines and polypharmacy. J Am Med Dir Assoc 2010;11:475-484.

40. Malmstrom TK, Morley JE. The frail brain. J Am Med Dir Assoc 2013;14:453-455

41. Morley JE. Anticholinergic medications and cognition. J Am Med Dir Assoc 2011;12:543-543.e1.

42. Morley JE. Alzheimer's disease: Future treatments. J Am Med Dir Assoc 2011;12:17.

43. Lam LC, Chau RC, Wong BM, et al. A 1-year randomized controlled trial comparing mind body exercise (Tai Chi) with stretching and toning exercise on cognitive function in older Chinese adults at risk of cognitive decline. J Am Med Dir Assoc 2012;13:568.e15-20

44. Yamada M, Arai H, Sonoda T, Aoyama T. Community-based exercise program is cost-effective by preventing care and disability in Japanese frail older adults. J Am Med Dir Assoc 2012;13:507-511.

45. Valenzuela T. Efficacy of progressive resistance training interventions in older adults in nursing homes: A systematic review. J Am Med Dir Assoc 2012;13:418-428.

46. Singh NA, Quine S, Clemson LM, et al. Effects of high-intensity progressive resistance training and targeted multidisciplinary treatment of frailty on mortality and nursing home admission after hip fracture: A randomized controlled trial. J Am Med Dir Assoc 2012;13:24-30.

47. Rolland Y, Abellan van Kan G, Vellas B. Physical activity and Alzheimer's disease: From prevention to therapeutic perspectives. J Am Med Dir Assoc 2008;9:390-405.

48. Morley JE. The magic of exercise. J Am Med Dir Assoc 2008;9:375-377.

49. Chu LW, Tam S, Wong RL, et al. Bioavailable testosterone predicts a lower risk of Alzheimer's disease in older men. J Alzheimers Dis 2010;21:1335-1345.
50. Chu LW, Tam S, Lee PW, et al. Bioavailable testosterone is associated with a reduced risk of amnestic mild cognitive impairment in older men. Clin Endocrinol (Oxf). 2008;68:589-598

51. Flood JF, Farr SA, Kaiser FE, et al. Age-related decrease of plasma testosterone in SAMP8 mice: Replacement improves age-related impairment of learning and memory. Physiol Behav 1995;57:669-673.

52. Farr SA, Price TO, Banks WA, et al. Effect of alpha-lipoic acid on memory, oxidation, and lifespan in SAMP8 mice. J Alzheimers Dis 2012;32:447-455.

53. Shah R. The role of nutrition and diet in Alzheimer disease: A systematic review. J Am Med Dir Assoc 2013;14:398-402.

54. Kamphuis PJ, Verhey FR, Olde Rikkert MG, et al. Efficacy of a medical food on cognition in Alzheimer's disease: Results from secondary analyses of a randomized, controlled trial. J Nutr Health Aging 2011;15:720-724.

55. Kamphuis PJ, Verhey FR, Olde Rikkert MG, et al. Effect of a medical food on body mass index and activities of daily living in patients with Alzheimer's disease: Secondary analyses from a randomized, controlled trial. J Nutr Health Aging 2011;15:672-676.

56. Flaherty JH, Dong B, Wu H, et al. Observational study of 1-year mortality rates before and after a major earthquake among Chinese nonagenarians. J Gerontol A Biol Sci Med Sci 2011;66:355-361.

57. Chau PH, Yen E, Morley JE, Woo J. The effects of environmental stressors on the mortality of the oldest old male population in Hong Kong, 1977-2006. Aging Male 2008;11:179-188.

58. Morley JE. Depression in nursing home residents. J Am Med Dir Assoc 2010;11:301-303

59. Thakur M, Blazer DG. Depression in long-term care. J Am Med Dir Assoc 2008;9:82-87. 